\title{
Keefektifan pendekatan kontekstual berbasis budaya lokal ditinjau dari prestasi, minat belajar, dan apresiasi terhadap matematika
}

\author{
Eka Sulistyawati \\ Program Studi Tadris Matematika, Institut Agama Islam Negeri Kediri, Indonesia \\ E-mail: ekasulistyawati13@gmail.com
}

\begin{abstract}
ABSTRAK
Penelitian ini mendeskripsikan keefektifan pendekatan kontekstual berbasis budaya lokal dan pendekatan konstekstual dalam pembelajaran matematika dan pendekatan pembelajaran yang lebih efektif diantara pendekatan kontekstual dan pendekatan kontekstual berbasis budaya lokal ditinjau dari prestasi belajar, minat belajar dan apresiasi siswa terhadap matematika. Penelitian ini adalah penelitian eksperimen semu dengan pretest-posttest control group design. Populasi penelitian ini adalah siswa kelas VIII SMP Negeri 4 Girimulyo yang memiliki karakteristik yang sama. Sampel penelitian ini adalah 2 kelas yang dipilih secara acak dari seluruh populasi. Data hasil penelitian dianalisis menggunakan Multivariate Analysis of Variance (MANOVA) untuk mengidentifikasi perbedaan keefektifan antara pendekatan kontekstual berbasis budaya lokal dan pendekatan kontekstual. Untuk mengetahui pendekatan yang lebih efektif diantara pendekatan kontekstual berbasis budaya lokal dan pendekatan kontekstual data dianalisis menggunakan univariate independent sample t-test. Untuk mengetahui keefektifan pembelajaran matematika menggunakan pendekatan kontekstual berbasis budaya lokal dan pendekatan kontekstual digunakan uji proporsi. Hasil penelitian ini adalah 1) Pendekatan kontekstual berbasis budaya lokal lebih efektif ditinjau dari prestasi belajar matematika, minat belajar dan apresiasi siswa terhadap matematika; 2) Pendekatan kontekstual efektif ditinjau dari prestasi belajar dan apresiasi siswa terhadap matematika; 3) Pendekatan kontekstual berbasis budaya lokal lebih efektif dibandingkan pendekatan kontekstual ditinjau dari apresiasi siswa terhadap matematika.
\end{abstract}

Kata Kunci : pendekatan kontekstual berbasis budaya lokal; prestasi belajar; minat belajar; apresiasi siswa terhadap matematika

\begin{abstract}
This study is describe the effectiveness using contextual based on local culture approach and contextual approach in teaching mathematics and the more effective teaching between contextual based on local culture approach and contextual approach based on student achievement, learning interest, and students appreciation toward mathematics. This research is a quasi-experimental design with nonequivalent groups pretest-posttest control group design. The research population are all of year VIII students that have same characteristic with students in SMP Negeri 4 Girimulyo. The sample consist of two classes that were randomly established from SMP Negeri 4 Girimulyo. The data were analyzed by Multivariate Analysis of Variance (MANOVA) to identify the differences of effectiveness between contextual based on local culture class and contextual class. To see the more effective approach between contextual based on local culture approach and contextual approach the data were analyzed by univariate independent sample t-test. To test the effectiveness of mathematics teaching using contextual based on local culture approach and contextual approach, a proportion test was used. The results of the study shows that: 1) Contextual based on local culture approach are effective in teaching mathematics based on students' learning achievement, students' learning interest and appreciation toward mathematics; 2) Contextual approach are effective in teaching mathematics based on students' learning achievement and appreciation toward mathematics; 3) Contextual based on local culture approach is more effective than contextual approach based on students' appreciation toward mathematics.
\end{abstract}

Keywords: contextual approach based on local culture; learning achievement; learning interest; appreciation toward mathematics. 


\section{PENDAHULUAN}

Tujuan dari pelaksanaan pembelajaran matematika adalah mengetahui kebermanfaatan matematika serta memiliki keingintahuan, minat belajar dan keingintahuan terhadap materi matematika. Beberapa kompetensi yang diharapkan oleh Peraturan Menteri Pendidikan Nasional Nomor 22 tahun 2006 yakni perhatian siswa dan rasa ingin tahu berhubungan erat dengan minat. Minat diartikan sebagai adanya rasa ingin tahu atau ketertarikan pada suatu ide pemikiran atau kejadian dengan melibatkan perhatian. (Collette \& Chiappetta ,1994, p.74).

Selain pentingnya minat belajar sebagai tujuan pembelajaran matematika, Baumert, et al, (Frenzel, Goetz, Pekrun, \& Watt, 2010, p.508) mengemukakan bahwa minat sangat menentukan kualitas suatu proses pembelajaran. Hal lain yang berkaitan dengan pentingnya minat dalam pembelajaran diperoleh dari penelitian yang dilakukan oleh Köller, Baumert dan Schanabel (2001, p.448) yang meneliti minat dari 602 siswa tingkat 7 sampai 10. Dalam penelitan ini dihasilkan bahwa, siswa yang memiliki prestasi tinggi memiliki minat yang lebih tinggi dibandingkan siswa yang berprestasi rendah. Penelitian lain mengemukakan bahwa kurangnya minat pada topik tertentu memperoleh peringkat tertinggi sebagai alasan untuk kegagalan siswa di sekolah selain tingkat kesulitan tugas, strategi, usaha, kemampuan, keberuntungan, pengaruh guru, dan pengaruh keluarga (Vispoel \& Austin, 1995, p.386). Hal lain yang berhubungan dengan pentingnya minat dalam pembelajaran dikemukakan oleh Schunk, Meece, \& Pintrich (2010, p.211) yang mengemukakan bahwa minat memberikan pengaruh terhadap baik dan tidaknya kegiatan belajar dan bekerja. Beberapa pendapat dan penelitian di atas telah memberikan gambaran mengenai pentingnya minat dalam kegiatan pembelajaran.

Pemenuhan kompetensi siswa berupa minat sangat berhubungan dengan kompetensi yang lain yaitu prestasi belajar. Ainley, Hidi \& Berndorf (Woolfolk, 2009, p.205) mengemukakan bahwa mrespon positif terhadap suatu materi dipengaruhi oleh besar kecilnya minat yang kemudian akan mengakibatkan pemrosesan dan prestasi yang lebih tinggi dan mendalam sehingga akan berpengaruh terhadap kuat lemahnya ingatan tentang materi dan prestasi. Pendapat di atas memiliki makna bahwa minat belajar mendukung terhadap prestasi belajar siswa. Siswa yang memiliki minat belajar rendah tidak dapat memperoleh prestasi yang maksimal. Begitu pula sebaliknya, siswa yang memiliki minat yang tinggi akan memperoleh prestasi belajar yang maksimal. Kurangnya prestasi belajar matematika akan sangat berpengaruh terhadap aspek-aspek pembelajaran yang lain. Hal ini disebabkan, matematika adalah sumber ilmu yang lain (Suherman, et.al, 2003. p.25). Hal ini berarti bahwa banyak pengembangan dan ilmu-ilmu penemuan lainnya sangat bergantung dari matematika.

Pentingnya minat dan prestasi belajar menumbuhkan usaha pendidik untuk meningkatkan minat dan prestasi belajar siswanya. Usaha guru untuk memaksimalkan minat belajar dan prestasi belajar matematika dapat dilakukan dengan memvariasi metode dan pendekatan pembelajaran yang digunakan. Dalam praktik pembelajaran di kelas guru sebagai fasilitator dapat mengadakan kegiatan pembelajaran yang mengarahkan siswa untuk menghargai, mengenaili dan membangun pengetahuan matematikanya (Reys, Lindquist, Lambdin, \& Smith, 2014, p.2). Hal ini sesuai dengan instruksi pemerintah yakni guru disarankan untuk melakukan pembelajaran matematika yang dimulai dengan pengenalan masalah yang sesuai dengan konteks (contextual problem). Pendekatan kontekstual adalah satu dari beberapa pendekatan pembelajaran yang mengintegrasikan contextual problem dalam proses pembelajaran. 
Pendekatan kontekstual dikenal sebagai pendekatan pembelajaran yang menghubungkan materi pembelajaran dengan konteks kehidupan nyata (Sears, 2002, p.2). Penggunaan pendekatan kontekstual dalam proses pembelajaran terutama dalam pembelajaran matematika telah banyak dipraktikkan oleh guru-guru di Indonesia. Hal ini dibuktikan dengan banyaknya penelitian tentang penggunaan pendekatan kontekstual seperti Zahman (2012) yang meneliti efektifitas penggunaan pendekatan kontekstual dalam pembelajaran matematika dilihat dari kemampuan penalaran, komunikasi matematika dan pencapaian kompetensi dasar. Berdasarkan penelitian tersebut dapat diketahui data hasil tes pencapaian kompetensi dasar kelas yang menggunakan pendekatan kontekstual adalah sebagai berikut:

Tabel 1. Hasil Tes Pencapaian Kompetensi Dasar Kelas yang Menggunakan Pendekatan Kontekstual Zahman (2012, p.104)

\begin{tabular}{lll}
\hline Deskripsi & Pretest & Posttest \\
\hline Rata-rata & 28,536 & 69,679 \\
\hline Nilai Maksimum & 52 & 89 \\
\hline Nilai Minimum & 9 & 54 \\
\hline Standar Deviasi & 11,955 & 9,969 \\
\hline
\end{tabular}

Tabel 1 menginformasikan kenaikan nilai pretest dan postest siswa secara signifikan dapat diperoleh melalui penerapan pendekatan kontekstual. Walaupun berdasarkan nilai standar deviasi posttest dapat diketahui bahwa terjadi rentang atau simpangan yang besar pada nilai posttest siswa yang menggunakan pendekatan kontekstual yang berarti bahwa pencapaian kompetensi dasar siswa yang menggunakan pendekatan kontekstual belum merata. Belum meratanya kemampuan siswa yang ditunjukkan dengan nilai standar deviasi posttest yang tinggi mengharuskan guru untuk melakukan variasi pembelajaran yang dapat menumbuhkan pemahaman, kesan yang baik, dan pengalaman yang mengesankan bagi siswa dengan memanfaatkan objek pengamatan yang dekat dengan siswa. Dengan adanya objek pengamatan yang dekat dengan siswa yang dihubungkan dengan materi pembelajaran diharapkan dapat menumbuhkan kesan yang baik, pemahaman, dan aktifitas belajar yang bermakna baik bagi siswa. Selain itu, penggunaan objek pengamatan yang dekat dengan siswa dapat memberikan kemampuan praktis yang dapat digunakan oleh siswa untuk memahami kebergunaan materi pembelajaran pada kehidupan sehari-harinya. Kehidupan sehari-hari masyarakat tidak lepas dari aktifitas budaya sehingga objek kajian yang diamati dalam kehidupan sehari-hari siswa sangat erat hubungannya dengan aktifitas budaya. Oleh karena itu dalam proses pembelajaran dapat diintegrasikan aktifitas dan bentuk-bentuk budaya di dalamnya sebagai objek kajian siswa.

Pelaksanaan proses pembelajaran di sekolah tidak hanya ditentukan oleh pemerintah pusat, guru dan siswa saja namun pemerintah daerahpun juga turut andil dalam meningkatkan kualitas pendidikan di daerahnya. Hal ini dilakukan oleh pemerintah daerah melalui peraturan-peraturan daerah tentang pendidikan yang salah satunya adalah Rencana Strategi Pembangunan Daerah dalam Peraturan Gubernur DIY Nomor 77 tahun 2012 yang menyarankan untuk mengintegrasikan budaya lokal. Hal ini adalah dalam rangka pemenuhan pelaksanaan visi misi DIY sebagai pusat pendidikan berbasis budaya di Asia Tenggara yang terkemuka. Visi dan misi DIY yang dituangkan dalam peraturan tersebut dilandasi pada budaya lokal adalah kebudayaan yang bermutu tinggi, bernilai dan wajib untuk dipelihara. Penggunaan budaya dapat diintegrasikan sebagai penguat tujuan pendidikan, budaya sebagai pendekatan dan pengelolaan pendidikan dan sebagai muatan atau isi pendidikan. Oleh karena itu untuk mendukung keterlaksanaan visi misi DIY diperlukan suatu pendekatan atau strategi pembelajaran yang mengintegrasikan nilai luhur budaya sebagai muatan atau isi materi pembelajaran. 
Pendekatan kontekstual adalah satu dari sekian banyak pendekatan pembelajaran yang dapat mengintegrasikan nilai luhur budaya sebagai muatan atau isi materi pembelajaran. Pengintegrasian nilai luhur budaya dalam muatan atau isi materi pembelajaran dapat dilakukan dalam langkah pembelajaran relating . Langkah ini mengharuskan guru untuk menghubungkan materi pembelajaran dengan objek kajian budaya agar siswa dapat mengetahui keterkaitan antara objek kajian budaya dengan materi matematika yang dipelajari. Pengintegrasian objek kajian budaya dalam materi matematika merupakan salah satu bentuk usaha warga negara Indonesia untuk mempertahankan dan melestarikan budaya lokal. Beberapa objek kajian budaya yang dapat diintegrasikan dengan materi matematika adalah permainan tradisional. Permainan tradisional memiliki nilai edukasi baik dipandang dari aspek motorik, kognitif dan sosial. Misalnya saja dalam permainan "delikan" atau petak umpet apabila dilihat dari aspek motori permainan tersebut mengajarkan pemain untuk berlari dan menyepak, sedangkan apabila dilihat dari aspek kognitif pemain dilatih untuk menentukan berapa orang yang sudah ditemukan dan berapa jumlah siswa orang yang belum ditemukan, melatih kecermatan dll. Di sisi lain apabila dipandang dari aspek sosial permainan ini mengharuskan pemain untuk bersosialisasi dan berinteraksi dengan teman yang lain. Tingginya nilai objek budaya lokal tersebut belum diiringi dengan kebiasaan masyarakat yang cenderung terbawa arus perkembangan globalisasi. Di Era sekarang banyak dikenal permainan online seperti playstasion dan game online di smartphone. Dipandang dari aspek kognitif permainan online dapat mengajarkan kecermatan, ketangkasan dan kecepatan pemainnya. Namun apabila dipandang dari aspek sosial dan motorik, permainan online tidak mengajarkan kebersamaan, saling tolong menolong, berlatih berinteraksi dengan orang lain, menghormati dengan yang lebih tuas, dll. Oleh karena itu, pengintegrasian budaya dalam pembelajaran merupakan sesuatu yang penting dalam rangka melestarikan warisan budaya Indonesia. Menurut National Council of Teachers of Mathematics (2000, p.4) matematika adalah bagian dari budaya. Sehingga siswa diharapkan siswa dapat memiliki pemahaman, apresiasi/penilaian yang baik terhadap matematika. Barret (2007, p.650) berpendapat bajwa apresiasi diartikan sebagai hasil dari penilaian baik atau buruk terhadap suatu hal baik berupa objek ataupun aktifitas tertentu.

Apresiasi terhadap matematika merupakan salah satu dari banyak aspek yang penting dan harus dikembangkan dalam proses pembelajaran. Oleh karena itu diperlukan suatu cara untuk menumbuhkan apresiasi terhadap matematika. Seperti penelitian yang dilakukan oleh Kisker, et. al (2012, p.79) yang mengembangkan modul yang sesuai dengan suplemen kurikulum berbasis budaya. Berdasarkan penelitian tersebut diperoleh hasil bahwa modul yang dikembangkan yaitu Picking Berries dan Going to Egg Island meningkatkan prestasi siswa terhadap matematika secara signifikan.

Oleh karena itu berdasarkan beberapa alasan di atas perlu dilaksanakan penelitian eksperimen untuk mengetahui keefektifan pembelajaran matematika dengan menerapkan pendekatan kontekstual berbasis budaya lokal yang ditinjau dari prestasi belajar, minat belajar matematika siswa, dan apresiasi siswa terhadap matematika untuk siswa SMP serta untuk mendeskripsikan manakah pendekatan yang lebih efektif diantara pendekatan kontekstual berbasis budaya lokal dan pendekatan kontekstual apabila ditinjau dari prestasi belajar, minat belajar, dan apresiasi siswa terhadap matematika pada materi lingkaran.

Pembelajaran matematika dengan pendekatan kontekstual dilaksanakan melalui langkahlangkah REACT (Relating: belajar dalam konteks pengalaman hidup; Experiencing: belajar melalui eksplorasi, discovery, dan penemuan; Applying: belajar ketika pengetahuan diperkenalkan dalam konteks penggunaannya dalam pemecahan masalah nyata; Cooperating: belajar melalui konteks pembagian tugas, tanya jawab, dan berkomunikasi dengan pembelajar yang lain; Transferring: menerapkan pengetahuan untuk situasi 
atau konteks baru) (Center for Occupational Research and Development, 1999, pp.2230; Crawford, 2001, pp.3-8; Williams, 2007, p.573). Untuk melaksanakan pembelajaran matematika dengan pendekatan kontekstual berbasis budaya lokal, perlu kajian mengenai budaya. Budaya diketahui sebagai kata majemuk dari budi-daya, yang artinya adalah "daya dan budi". Hal ini berarti bahwa budaya adalah hasil dari budidaya atau cipta manusia (Koentjaraningrat, 2009, p.146). Hasil budi daya manusia yang dapat berupa ketrampilan, pengetahuan, tradisi, kepercayaan, aturan, karya seni, dan tingkah laku yang merupakan hasil suatu generasi untuk diteruskan ke generasi berikutnya (Woolfolk, 2009, p.241), (Ormrod, 2008, p.118).

Untuk mengetahui wujud-wujud budaya, Deal \& Peterson (1999, pp.23-68) mengemukakan bahwa terdapat beberapa wujud budaya diantaranya yaitu (1) vision and value; (2) ritual and ceremony yang di dalamnya terdapat ritual, ceremony, dan tradisions; (3) history and stories; (4) architecture and artifacts. Hal ini bermakna bahwa terdapat empat wujud budaya yaitu pandangan dan nilai, upacara keagamaan dan peringatan, sejarah dan cerita, serta arsitektur dan benda-benda. Pendapat lain mengatakan bahwa budaya dapat berupa (1) ide, nilai, norma, gagasan dan peraturan, (2) tindakan dan aktifitas berpola masyarakat, dan (3) hasil karya manusia berupa benda (Koentjaraningrat, 2009, p.150). Oleh karena itu terdapat beberapa wujud budaya yaitu ide, visi, gagasan, nilai, norma, peraturan sebagai wujud budaya yang bersifat abstrak dan benda-benda fisik dan budaya yang berupa sistem sosial (aktifitas-aktifitas manusia yang berinteraksi, berhubungan, dan bergaul satu sama lain dari waktu ke waktu menurut pola dan tata aturan tertentu yaitu aktifitas (ritual,tradisi dan upacara), perbuatan karya manusia (sejarah dan cerita) sebagai wujud budaya yang bersifat konkret.

Untuk menggunakan budaya lokal dalam pembelajaran matematika harus terlebih dahulu dikaji mengenai pengertian kata lokal. Lokal berarti tempat, wilayah setempat. Oleh karena itu dapat diketahui bahwa budaya lokal adalah hasil rasa, karya, dan cipta manusia yang berupa ide, aktifitas, dan benda-benda fisik dari suatu masyarakat di wilayah tertentu. Budaya sangat perlu dihasilkan dan diteruskan sebagai alat untuk berkomunikasi satu generasi ke generasi lainya, agar manusia mengetahui hasil budidaya manusia dari masingmasing generasi. Dalam penelitian digunakan beberapa wujud budaya lokal yang berupa permainan tradisional, tari dan kesenian tradisional, upacara adat dan keagamaan yang dapat dipandang sebagai wujud budaya konkret yaitu aktifitas, dan motif batik, bendabenda peninggalan sejarah yang dipandang sebagai wujud budaya konkret yaitu arsitektur dan artefak.

Oleh karena itu pelaksanaan pembelajaran matematika dengan pendekatan kontekstual berbasis budaya lokal dilakukan melalui langkah-langkah (1) Relating, yaitu guru memberi contoh kebergunaan matematika dalam kehidupan budaya siswa. Hal ini dapat dilakukan dalam kegiatan apersepsi dan motivasi. Dalam kegiatan apersepsi guru menunjukkan tampilan berupa gambar atau video yang berisi macam-macam motif batik, permainan tradisional, upacara adat dan keagamaan, benda-benda peninggalan sejarah, tari dan kesenian tradisional khas Jawa. Secara lebih khusus, permainan tradisional, upacara adat dan keagamaan, benda-benda peninggalan sejarah dan kesenian tradisional khas Jawa dijelaskan pula dalam LKS. Beberapa tampilan tersebut bertujuan untuk membantu membangkitkan pengetahuan siswa yang telah ada dan membantu siswa untuk mengkaitkan pengetahuan tersebut dengan relevansi matematika dalam kehidupan keseharian siswa, (2) Experiencing, dalam proses ini siswa diharuskan melakukan aktifitas belajar dalam rangka menemukan dan memahami materi matematika dengan bantuan LKS. LKS berisi prosedur yang membantu siswa untuk menemukan konsep matematika. Dalam proses ini siswa melakukan aktifitas melukis motif Batik Kawung sebagai salah satu motif batik yang 
terbentuk dari bentuk-bentuk geometris yaitu lingkaran, mendemonstrasikan permainan "othok-othok" untuk melakukan penelusuran bilangan pi $(\pi)$, mendemonstrasikan cara memainkan alat musik Rebana yang memiliki hubungan dengan luas lingkaran, bercerita tentang legenda Goa Kiskendo dan Goa Sumitro yang memiliki hubungan dengan materi lingkaran dalam segitiga, dan mendemonstrasikan gerakan Tari Angguk sebagai salah satu gerakan kreasi baru yang menerapkan konsep segitiga dalam lingkaran. Dalam proses ini, terdapat permasalahan yang berhubungan dengan budaya dan matematika dan harus diselesaikan siswa. Dalam proses ini, digunakan model untuk mendemonstrasikan apa yang akan dibahas. Model dalam proses pembelajaran dapat dilakukan oleh guru maupun siswa. Model bertugas memberikan contoh aktifitas yang akan dilakukan dalam rangka menemukan konsep matematika. Selain itu, dalam proses pengerjaan LKS, guru bertugas untuk membimbing dan mengarahkan, agar proses menemukan konsep matematika menjadi serangkaian kegiatan yang jelas dan terarah. (3) Applying, dalam proses ini siswa menggunakan konsep yang ia temukan untuk menyelesaikan permasalahan yang bermakna terkait dengan budaya lokal. Permasalahan ini telah tertulis dalam LKS. (4) Cooperating, dalam proses ini siswa diharuskan melakukan aktifitas bekerja kelompok dalam kelompokkelompok kecil. Bersama dengan kelompoknya siswa dapat saling membantu satu dengan lainnya untuk memahami materi pelajaran, membangun hubungan yang baik dengan siswa yang lain, mengajarkan siswa untuk berani berpendapat, dan menghargai pendapat siswa satu dengan siswa yang lain, dan (5) Transferring, siswa menerapkan pengetahuannya untuk menyelesaikan konteks permasalahan yang baru. Dalam langkah ini, guru menyediakan persoalan yang dapat melatih siswa untuk menggunakan pengetahuannya untuk menyelesaikan permasalahan yang baru. Selain itu, dalam proses ini siswa diberi kesempatan untuk mengemukakan hasil diskusinya dalam menemukan konsep matematika ataupun dalam menemukan penyelesaian permasalahan matematika.

\section{METODE PENELITIAN}

Subjek penelitian ini adalah siswa kelas VIII A dan VIII B SMP Negeri 4 Girimulyo Tahun Ajaran 2014/2015 yang masing-masing terdiri 22 dan 23 siswa. Penelitian ini merupakan eksperimen semu dengan desain penelitian nonequivalent groups pretest-posttest control group design (McMillan \& Schumacher, 2010, p.343). Desain ini menggunakan dua kelas eksperimen. Kelas eksperimen pertama adalah kelas yang menerapkan pembelajaran dengan pendekatan kontekstual berbasis budaya lokal dan kelas eksperimen kedua adalah kelas yang menerapkan pembelajaran dengan pendekatan kontekstual. Teknik pengumpulan data dalam penelitian ini adalah pengumpulan data sebelum diberikan perlakuan yaitu dengan memberikan pretest prestasi belajar, angket minat belajar, dan angket apresiasi siswa terhadap matematika. Selanjutnya penelitian dilakukan dengan memberi perlakuan di kelas ekserimen pertama dan kedua. Setelah kedua kelas eksperimen diberikan perlakuan diberikan posttest yang mengukur prestasi belajar yang berupa soal, angket apresiasi siswa terhadap matematika dan minat belajar yang diukur dengan angket. Instrumen penelitian yang berupa angket diujicobakan untuk mengetahui keajegan instrumen angket. Berdasarkan ujicoba instrumen angket minat belajar matematika dan angket apresiasi siswa terhadap matematika diperoleh koefisien reliabilitas instrumen berturut-turut sebesar 0,887 dan 0,840. Berdasarkan nilai koefisien reliabilitas dapat diketahui nilai Standart Error of Measurement (SEM) untuk angket minat belajar dan angket apresiasi siswa terhadap matematika berturut-turut adalah sebesar 3,94 dan 3,50.

Nilai SEM digunakan untuk menentukan interval kepercayaan skor sebenarnya. Dipilih tingkat kepercayaan sebesar $68 \%$ sehingga dapat diketahui interval kepercayaan skor 
sebenarnya melalui perhitungan berikut:

$$
x-s_{E} \leq T \leq x+s_{E}
$$

Keterangan :

$\mathrm{x}$ : Skor perolehan siswa

$\mathrm{z}_{\mathrm{c}}$ : nilai kritis dari deviasi standar normal (1)

$\mathrm{S}_{\mathrm{E}}:$ SEM

Apabila dipilih tingkat kepercayaan lain yaitu $95 \%$, interval kepercayaan skor sebenarnya ditentukan dengan rumus berikut:

Keterangan :

$$
x-\left(1,96 \times s_{E}\right) \leq T \leq x+\left(1,96 \times s_{E}\right)
$$

$\mathrm{x}$ : Skor perolehan siswa

$\mathrm{z}_{\mathrm{c}}$ : nilai kritis dari deviasi standar normal $(1,96)$

$\mathrm{S}_{\mathrm{E}}:$ SEM

Penelitian ini menggunakan teknik analisis data secara deskriptif dan inferensial. Analisis deskriptif untuk mendeskripsikan keadaan sebelum dan sesudah diberikan perlakuan pada kedua kelas ditinjau dari masing-masing variabel terikatnya. Analisis inferensial dilakukan untuk mengambil kesimpulan berdasarkan data yang telah diperoleh selama proses penelitian berlangsung. Analisis inferensial ini terdiri dari uji keefektifan dan uji perbandingan keefektifan pembelajaran matematika.

Sebelum dilakukan analisis keefektifan secara inferensial, perlu diketahui keefektifan pembelajaran matematika dengan menggunakan pencapaian ketuntasan tujuan pembelajaran Dalam penelitian ini Pendekatan pembelajaran dikatakan efektif dilihat dari prestasi belajar apabila lebih dari $50 \%$ dari jumlah siswa memperoleh skor prestasi belajar lebih dari sama dengan 75. Sementara itu, suatu pendekatan pembelajaran dikatakan efektif ditinjau dari minat belajar dan apresiasi siswa terhadap matematika apabila lebih dari 50 $\%$ dari jumlah siswa memperoleh skor minat belajar dan apresiasi terhadap matematika dengan kategori tinggi dan sangat tinggi.

Analisis data menggunakan uji proporsi untuk mengetahui keefektifan dari pendekatan kontekstual berbasis budaya lokal dan pendekatan kontekstual berdasarkan variabel prestasi belajar, minat belajar dan apresiasi siswa terhadap matematika. Selanjutnya, untuk mengetahui ada tidaknya perbedaan keefektifan keefektifan antar kedua model pembelajaran dapat dilakukan dengan menerapkan uji Multivariate Analysis of Variance (MANOVA) $T^{2}$ Hotelling (Stevens, 2009, p.148) dengan menggunakan taraf signifikansi sebesar 0,05. Untuk mengetahui apakah pendekatan kontekstual berbasis budaya lokal lebih efektif dibandingkan dengan pendekatan kontekstual berbasis budaya lokal ditinjau dari prestasi belajar, minat belajar, dan apresiasi siswa terhadap matematika digunakan uji univariat menggunakan Independent sample t test dengan taraf signifikansi 0,0167.

\section{HASIL DAN PEMBAHASAN}

Hasil penelitian ini berdasarkan pada hasil uji keefektifan pendekatan pembelajaran dan uji perbandingan keefektifan pembelajaran menggunakan pendekatan kontekstual berbasis budaya lokal dan pendekatan kontekstual. Hasil uji keefektifan dengan menggunakan uji proporsi disajikan pada Tabel 2 . 
Tabel 2. Hasil Uji Keefektifan Pendekatan Pembelajaran

\begin{tabular}{llll}
\hline Pendekatan & Variabel & $\mathrm{Z}_{\text {hitung }}$ & $\mathrm{Z}_{\text {tabel }}$ \\
\hline \multirow{3}{*}{ Kontekstual } & Prestasi & 2,132 & 1,645 \\
& Minat & 0,4264 & 1,645 \\
& Apresiasi & 1,706 & 1,645 \\
Kontekstual & Prestasi & 2,711 & 1,645 \\
Berbasis & Minat & 1,876 & 1,645 \\
Budaya Lokal & Apresiasi & 3,545 & 1,645 \\
\hline
\end{tabular}

Tabel 2 menunjukkan bahwa pendekatan kontekstual efektif apabila dilihat dari variabel prestasi belajar, dan apresiasi siswa terhadap matematika. Apabila ditinjau dari aspek minat belajar matematika, pendekatan kontekstual tidak efektif. Sedangkan pendekatan kontekstual berbasis budaya lokal efektif apabila dilihat dari dari minat belajar, prestasi belajar dan apresiasi siswa terhadap matematika. Untuk menguji perbedaan keefektifan antara pembelajaran yang menggunakan pendekatan kontekstual berbasis budaya lokal dan pendekatan kontekstual dilakukan dengan uji multivariat $T^{2}$ Hotelling dengan bantuan SPSS. Berdasarkan uji tersebut diperoleh taraf signifikansi sebesar 0,026. Taraf signifikansi hasil perhitungan tersebut kurang dari 0,05 yang berarti terdapat perbedaan keefektifan antara kelas eksperimen satu dan kelas eksperimen dua ditinjau dari minat belajar, prestasi belajar, dan apresiasi siswa terhadap matematika. Untuk mengetahui pendekatan pembelajaran yang lebih efektif dilakukan uji independent sample t-test. Hasil uji tersebut disajikan dalam Tabel 3:

Tabel 3. Hasil Uji Univariat terhadap Masing-masing Variabel

\begin{tabular}{lll}
\hline Variabel & $\mathrm{t}$ & Signifikansi \\
\hline Prestasi & 0,169 & 0,4335 \\
Minat & 2,062 & 0,0225 \\
Apresiasi & 2,351 & 0,0115 \\
\hline
\end{tabular}

Berdasarkan tabel 3 dapat diketahui bahwa pendekatan kontekstual berbasis budaya lokal tidak lebih efektif dibandingkan dengan pendekatan kontekstual dilihat dari prestasi belajar walaupun berdasarkan hasil analisis deskriptif rata-rata skor prestasi belajar pada kelas yang menggunakan pendekatan kontekstual berbasis budaya lokal lebih tinggi daripada rata-rata skor prestasi dari kelompok siswa yang menggunakan pendekatan kontekstual. Oleh karena itu berdasarkan tabel uji univariat terhadap masing-masing variabel di atas dapat diketahui bahwa pembelajaran matematika dengan pendekatan kontekstual berbasis budaya lokal lebih efektif dibandingkan pembelajaran matematika dengan pendekatan kontekstual apabila ditinjau dari apresiasi siswa terhadap matematika. Analisis berdasarkan perolehan rata-rata skor prestasi belajar siswa pada setiap kompetensi dasar, diperoleh hasil sebagai berikut:

Tabel 4. Hasil Uji Univariat pada Masing-masing Kompetensi Dasar

\begin{tabular}{lrr}
\hline Kompetensi Dasar & $\mathrm{t}$ & Signifikansi \\
\hline 1.1 & $-0,195$ & 0,5770 \\
1.2 & $-3,813$ & 0,9995 \\
1.3 & 3,093 & \\
1.4 & 0,646 & \\
1.5 & $-2,001$ & 0,9740 \\
\hline
\end{tabular}


Berdasarkan tabel 4 diketahui bahwa pada kompetensi dasar 1.1, 1.2, 1.4, dan 1.5 prestasi belajar kelompok siswa yang menggunakan pendekatan kontekstual berbasis budaya lokal tidak lebih baik dibandingkan prestasi belajar kelompok siswa yang menggunakan pendekatan kontekstual. Apabila ditinjau berdasarkan kompetensi dasar 1.3, prestasi belajar kelompok siswa yang menggunakan pendekatan kontekstual berbasis budaya lokal lebih baik dibandingkan prestasi belajar siswa yang menggunakan pendekatan kontekstual.

Pendekatan pembelajaran yang digunakan guru dalam mengajar sebelumnya belum mencerminkan hubungan kebergunaan materi pembelajaran dengan materi yang dipelajari siswa. Hal ini menjadi salah satu penyebab siswa menjadi tidak mengetahui kebermanfaatan materi matematika dengan kehidupan sehari-hari dan kebergunaan matematika dalam konteks budaya yang sering siswa lihat.

Dengan kurangnya pengetahuan siswa mengenai kebermanfaatan matematika dalam kehidupan dan peristiwa budayanya menyebabkan siswa tidak memiliki kesadaran bahwa matematika penting dan sangat perlu bagi kehidupan mereka. Hal ini mengakibatkan kurangnya kesenangan dan ketertarikan siswa terhadap matematika maupun terhadap proses belajar matematika. Oleh karena itu, minat belajar matematika dan apresiasi siswa terhadap matematika menjadi belum optimal.

Pendekatan pembelajaran yang digunakan sebagai alternatif dalam penelitian ini adalah pendekatan kontekstual berbasis budaya lokal dan pendekatan kontekstual. Sebelum kedua kelas diberikan perlakuan berupa pembelajaran matematika dengan pendekatan kontekstual berbasis budaya lokal dan pendekatan kontekstual, kondisi awal siswa dilihat terlebih dahulu apakah siswa memiliki kemampuan yang sama atau tidak apabila ditinjau dari prestasi belajar, minat belajar, dan apresiasi siswa terhadap matematika. Dengan kata lain kondisi awal siswa apabila ditinjau dari prestasi belajar, minat belajar, dan apresiasi terhadap matematika homogen atau tidak. Setelah dilakukan analisis, hasil analisis menunjukkan bahwa dua kelompok siswa yaitu kelas VIII A dan kelas VIII B memiliki kemampuan yang sama atau homogen pada kondisi awal.

Tujuan dari penelitian ini adalah untuk mendeskripsikan keefektifan pendekatan pembelajaran dengan pendekatan kontekstual berbasis budaya lokal dan pendekatan kontekstual ditinjau dari prestasi belajar matematika, minat belajar matematika, dan apresiasi siswa terhadap matematika dan untuk mendeskripsikan ada tidaknya perbedaan keefektifan dari pembelajaran matematika melalui pendekatan kontekstual berbasis budaya lokal dan pembelajaran matematika dengan pendekatan kontekstual apabila ditinjau dari prestasi belajar, minat belajar, dan apresiasi siswa terhadap matematika. Selanjutnya, untuk mendekripsikan pembelajaran yang lebih efektif diantara pembelajaran dengan pendekatan kontekstual berbasis budaya lokal dibandingkan dengan pembelajaran dengan pendekatan kontekstual ditinjau dari prestasi belajar, minat belajar, dan apresiasi siswa terhadap matematika. Berdasarkan data serta hasil penelitian, beberapa hal yang berhubungan dengan tujuan penelitian.

Keefektifan pendekatan kontekstual berbasis budaya lokal dan pendekatan kontekstual ditinjau dari prestasi belajar, minat belajar, dan apresiasi siswa terhadap matematika siswa SMP N 4 Girimulyo dapat dilihat dari kriteria yang telah ditentukan untuk aspek prestasi belajar, minat belajar, dan apresiasi siswa terhadap matematika. Kriteria yang telah ditentukan untuk aspek prestasi belajar adalah siswa dikatakan berhasil apabila lebih dari $50 \%$ dari jumlah siswa memperoleh skor prestasi belajar lebih dari sama dengan 75, sedangkan untuk aspek minat belajar matematika dan aspek apresiasi siswa terhadap matematika, siswa dikatakan berhasil jika lebih dari $50 \%$ dari jumlah siswa memperoleh 
skor minat belajar dan apresiasi terhadap matematika dengan kategori tinggi dan sangat tinggi.

Pendekatan kontekstual berbasis budaya lokal dan pendekatan kontekstual diterapkan berturut-turut pada kelas VIII B dan VIII A di SMP N 4 Girimulyo. Selama kegiatan pembelajaran, siswa tampak lebih senang dan bersemangat dalam mengikuti pembelajaran. Melalui pembelajaran dengan pendekatan kontekstual berbasis budaya lokal dan pendekatan kontekstual ini, setiap siswa mengetahui relevansi atau kegunaan matematika dalam kehidupan dan peristiwa budaya yang sering siswa lihat. Selain itu melalui pembelajaran matematika dengan pendekatan kontekstual dan pendekatan kontekstual berbasis budaya lokal, siswa saling membantu bersama anggota kelompoknya untuk menyelesaikan tugas yang dberikan. Dengan adanya rasa tanggung jawab akan tugas kelompok, setiap siswa memiliki rasa untuk ikut campur dalam penyelesaian tugas dan terlibat aktif dalam proses pembelajaran matematika.

Berdasarkan data hasil posttest, skor minat belajar matematika, dan skor apresiasi siswa terhadap matematika, penerapan pembelajaran matematika dengan pendekatan kontekstual berbasis budaya lokal efektif ditinjau dari prestasi belajar, minat belajar matematika dan apresiasi siswa terhadap matematika. Apabila dilihat dari rata-rata skor minat belajar matematika dan skor apresiasi siswa terhadap matematika dari kelompok siswa yang menggunakan pendekatan kontekstual berbasis budaya lokal diperoleh hasil sebesar 91, 57. Perolehan rata-rata skor minat belajar matematika dan skor apresiasi siswa terhadap matematika sama-sama berada pada kategori tinggi. Oleh karena itu, dapat dikatakan bahwa rata-rata skor minat belajar dan skor apresiasi siswa terhadap matematika dari kelompok siswa yang menggunakan pendekatan kontekstual berbasis budaya lokal adalah tinggi.

Di sisi lain, pendekatan kontekstual berbasis budaya lokal efektif apabila ditinjau dari prestasi belajar matematika siswa. Perolehan skor prestasi belajar siswa yang menggunakan pendekatan kontekstual berbasis budaya lokal lebih unggul dibandingkan rata-rata skor prestasi belajar siswa yang menggunakan pendekatan kontekstual. Namun, apabila dilihat dari besarnya standar deviasi skor prestasi belajar matematika, standar deviasi skor prestasi belajar siswa yang menggunakan pendekatan kontekstual berbasis budaya lokal lebih besar dibandingkan standar deviasi skor prestasi belajar siswa yang menggunakan pendekatan kontekstual. Dengan tingginya nilai standar deviasi skor prestasi belajar siswa yang menggunakan pendekatan kontekstual berbasis budaya lokal dibandingkan nilai standar deviasi skor prestasi belajar siswa yang menggunakan pendekatan kontekstual menunjukkan bahwa prestasi belajar matematika siswa yang menggunakan pendekatan kontekstual lebih merata. Prestasi belajar matematika siswa yang menggunakan pendekatan kontekstual berbasis budaya lokal kurang merata, hal ini berarti bahwa terdapat siswa yang berprestasi sangat tinggi namun juga ada siswa yang berprestasi sangat rendah.

Perolehan skor minat belajar dan apresiasi terhadap matematika yang berada pada kategori tinggi pada kelompok siswa yang menggunakan pendekatan kontekstual berbasis budaya lokal disebabkan, dalam proses pembelajaran siswa aktif berdiskusi dan siswa diajak untuk melakukan aktifitas melukis, menggunting, menempel, memamerkan hasil karya, bercerita atau presentasi, berdemonstrasi, berlatih memainkan alat musik rebana, memainkan permainan tradisional, dan merancang atau mendesain gerakan kreasi Tari Angguk yang menggunakan konsep lingkaran luar segitiga. Melalui beberapa aktifitas tersebut, siswa menjadi terlibat aktif dalam kegiatan belajar matematika, memiliki ketertarikan dalam melaksanakan proses belajar matematika, dan gemar untuk belajar matematika. Selain itu, proses pameran hasil karya membuat siswa merasa senang hasil karya siswa dipamerkan dan dapat dilihat oleh siswa yang lain. Dengan diadakannya kegiatan pameran lukisan batik 
akan tumbuh rasa berkompetisi antar kelompok untuk menjadi penyaji pameran yang paling baik. Melalui kegiatan menggambar, menggunting, pameran, bercerita, dan demonstrasi siswa memiliki kesadaran bahwa matematika dekat dengan kehidupannya.

Melalui kegiatan pembelajaran dengan pendekatan kontekstual berbasis budaya lokal, siswa mengetahui bahwa matematika bermanfaat dalam peristiwa-peristiwa sehari-hari khususnya peristiwa yang berhubungan dengan budaya. Hal ini karena, siswa dilatih untuk menjadi pribadi yang dapat merancang atau mendesain motif batik khas Yogyakarta yaitu Batik Kawung, dilatih untuk bisa memainkan alat musik rebana, diberikan bekal mengenai cerita legenda suatu tempat agar siswa mengetahui asal mula suatu tempat. Pengetahuan mengenai asal mula suatu tempat tersebut, diharapkan agar siswa dapat menceritakan kembali kepada khalayak umum mengenai cerita asal mula suatu tempat. Hal inilah yang menjadikan siswa memiliki kesenangan dan ketertarikan terhadap matematika serta kesadaran bahwa materi matematika memberikan bekal ketrampilan dan pengetahuan bagi kehidupannya di masa yang akan datang. Sesuai dengan prinsip pembelajaran dengan pendekatan kontekstual yaitu prinsip ketergantungan (independence). Prinsip ketergantungan ini memperhatikan adanya keterkaitan antara proses pembelajaran dengan suatu konteks sehingga siswa memiliki keyakinan bahwa belajar merupakan aspek yang penting bagi kehidupan pada masa yang akan datang (Johnson, 2002, pp.26-36).

Selain itu, hasil penelitian tersebut sesuai dengan pendapat Schunk, Meece, \& Pintrich (2020, pp.220-221) yang membahas mengenai cara-cara yang dapat dilakukan untuk membangkitkan minat belajar siswa dapat dilakukan dengan menggunakan aktivitas yang bervariasi dan unik, dan pendapat Elliot, Kratochwill, \& Cook (2000, p.349) yaitu mengajak siswa untuk berpartisipasi pada tugas serta menjelaskan hubungannya dengan manfaat di luar kelas, memberikan kesempatan siswa untuk belajar dengan bekerja sama dengan siswa lainnya.

Pada kelas eksperimen kedua yang menerapkan pendekatan kontekstual, diperoleh hasil bahwa pendekatan kontekstual efektif ditinjau dari prestasi belajar matematika dan apresiasi siswa terhadap matematika. Hal ini disebabkan siswa mengetahui kebergunaan matematika dalam kehidupan sehari-hari yang menjadikan siswa tertantang untuk memiliki prestasi yang tinggi. Keefektifan pendekatan kontekstual apabila ditinjau dari prestasi belajar, didukung dengan pendapat yang dikemukakan oleh Cai, Kaiser, Perry, \& Wong (2009, pp.18-19) yang mengemukakan ciri-ciri pembelajaran yang efektif yaitu diantaranya mengaktifkan siswa melalui kegiatan penyelidikan dan merancang kegiatan pembelajaran kelompok. Hal ini dikarenakan dalam pelaksanaan pembelajaran matematika menggunakan pendekatan kontekstual mengharuskan siswa untuk melaksanakan kegiatan penelusuran konsep-konsep matematika melalui kegiatan kerja kelompok. Selain itu, siswa diminta untuk mengemukakan hasil diskusinya di depan kelas. Hal tersebut berarti bahwa dalam pembelajaran matematika dengan pendekatan kontekstual siswa tidak hanya diberitahu rumus atau konsep matematika oleh guru, tetapi juga melaksanakan penyelidikan, penelusuran, dan penemuan konsep-konsep matematika. Melalui beberapa kegiatan itulah pembelajaran matematika dengan pendekatan kontekstual efektif ditinjau dari prestasi belajar dan apresiasi siswa terhadap matematika.

Selain itu pembelajaran matematika dengan pendekatan kontekstual efektif ditinjau dari prestasi belajar dan apresiasi siswa terhadap matematika sesuai dengan hasil penelitian yang dilakukan oleh Kamaruddin, Ahmad, Amin, \& Alias (2011, p.305) yang menyatakan bahwa kelompok yang menggunakan pendekatan kontekstual memiliki skor yang lebih tinggi dibandingkan dengan kelompok yang menggunakan pendekatan non kontekstual. 
Di sisi lain apabila ditinjau dari minat belajar matematika, pendekatan kontekstual tidak efektif efektif. Tidak efektifnya pembelajaran matematika dengan pendekatan kontekstual apabila ditinjau dari minat belajar dikarenakan kelompok siswa yang menggunakan pendekatan kontekstual merasa iri dengan kelas yang menggunakan pendekatan kontekstual berbasis budaya lokal. Hal inilah yang mengakibatkan, siswa-siswa yang menggunakan pendekatan kontekstual merasa dibedakan dengan perlakuan siswa-siswa yang menggunakan pendekatan kontekstual berbasis budaya lokal. Adanya perasaan dibedakan dengan kelompok siswa yang menggunakan pendekatan kontekstual berbasis budaya lokal mengakibatkan rata-rata skor minat belajar matematika yang menggunakan pendekatan kontekstual lebih rendah dibandingkan rata-rata skor minat belajar matematika yang menggunakan pendekatan kontekstual berbasis budaya lokal.

Dalam proses pembelajaran, pembelajaran matematika dengan pendekatan kontekstual dan pendekatan kontekstual berbasis budaya lokal melalui proses yang sama yaitu mengharuskan siswa untuk melakukan penelusuran konsep-konsep matematika melalui kegiatan diskusi kelompok, presentasi, dan penyimpulan bersama, hanya saja kelas yang menggunakan pendekatan kontekstual berbasis budaya lokal menggunakan relevansi matematika dalam peristiwa budaya seperti menggambar motif batik, pameran motif batik, demonstrasi dan pelatihan memainkan alat musik rebana, demostrasi permainan tradisional, cerita atau legenda suatu tempat, dan pengenalan gerakan Tari Angguk yang semuanya dihubungkan dengan materi lingkaran.

Salah satu contoh wujud budaya yang dihubungkan dengan unsur-unsur lingkaran adalah Batik Kawung. Berikut ini adalah motif dasar Batik Kawung yang terbentuk dari gabungangabungan lingkaran.

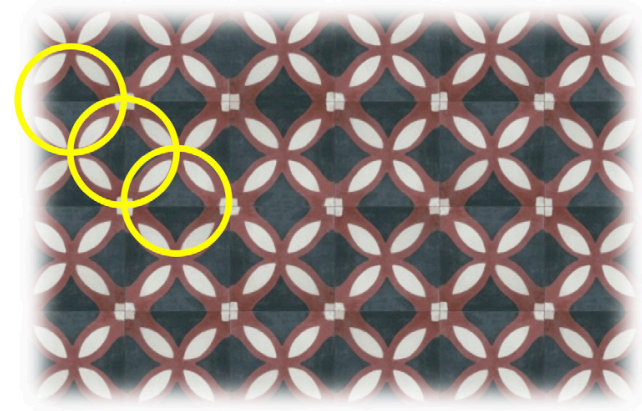

Gambar 1. Batik Kawung Picis

Dalam langkah experiencing, siswa diminta untuk melukis motif Batik Kawung dengan dipandu langkah-langkah di dalam LKS. Desain dasar motif Batik Kawung adalah sebagai berikut:

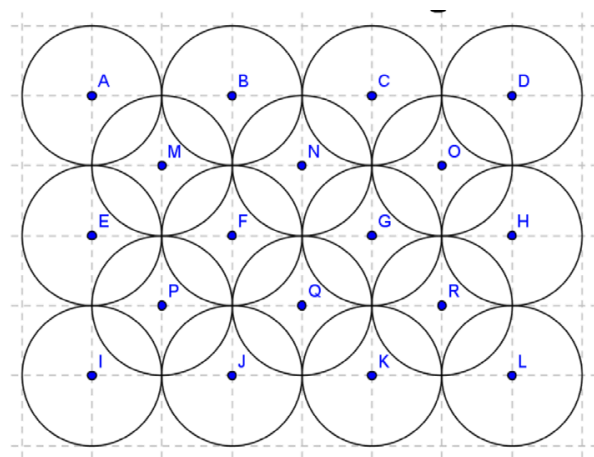

Gambar 2. Motif Dasar Batik Kawung 
Dalam pelaksanaannya pembelajaran pada pertemuan siswa yang menggunakan pendekatan kontekstual dalam pembelajaran memiliki waktu yang lebih banyak untuk melaksanakan kegiatan tanya jawab yang berhubungan dengan unsur-unsur lingkaran. Dengan adanya kesempatan yang lebih banyak untuk melaksanakan kegiatan tanya jawab mengakibatkan siswa lebih menguasai materi matematika yang dipelajari. Hal ini juga menjadi hal yang mengakibatkan nilai standar deviasi kelompok siswa yang menggunakan pendekatan kontekstual lebih kecil dibandingkan dengan nilai standar deviasi kelompok yang menggunakan pendekatan kontekstual berbasis budaya lokal.

Dari uraian di atas, dapat disimpulkan bahwa pendekatan kontekstual berbasis budaya lokal dan pendekatan kontekstual efektif ditinjau dari prestasi belajar, minat belajar matematika dan apresiasi siswa terhadap matematika. Oleh karena itu, perlu diketahui pendekatan manakah yang lebih efektif apabila ditinjau dari masing-masing variabel terikat yaitu prestasi belajar, minat belajar, dan apresiasi siswa terhadap matematika.

Berdasarkan hasil uji multivariat kondisi akhir diperoleh hasil bahwa prestasi belajar, minat belajar matematika, dan apresiasi siswa terhadap matematika dari kelompok yang menggunakan pendekatan kontekstual berbasis budaya lokal dan kelompok yang menggunakan pendekatan kontekstual adalah berbeda. Hal ini berarti bahwa apabila dianalisis secara bersama-sama, kedua kelompok siswa memiliki kemampuan yang berbeda setelah diberikan perlakuan berupa pembelajaran matematika dengan pendekatan kontekstual berbasis budaya lokal dan pendekatan kontekstual. Adanya perbedaan kemampuan apabila ditinjau secara bersama-sama berdasarkan prestasi belajar, minat belajar, dan apresiasi siswa terhadap matematika mengharuskan untuk melanjutkan analisis secara sendiri-sendiri berdasarkan masing-masing variabel terikat. Pengujian dilakukan dengan menggunakan independent sample t test pada masing-masing aspek yaitu prestasi belajar, minat belajar, dan apresiasi siswa terhadap matematika.

Berdasarkan hasil uji univariat dengan bantuan SPSS diperoleh hasil bahwa pembelajaran matematika dengan pendekatan kontekstual berbasis budaya lokal tidak lebih efektif dibandingkan dengan pendekatan kontekstual ditinjau minat belajar matematika. Walaupun pendekatan kontekstual berbasis budaya lokal tidak lebih efektif dibandingkan dengan pendekatan kontekstual apabila ditinjau dari minat belajar matematika, rata-rata skor minat belajar pada kelompok siswa yang menggunakan pendekatan kontekstual berbasis budaya lokal lebih unggul dibandingkan dengan rata-rata skor minat belajar pada kelompok siswa yang menggunakan pendekatan kontekstual. Hal lain yang memperkuat bahwa rata-rata skor minat belajar matematika siswa yang mengikuti pembelajaran matematika dengan pendekatan kontekstual berbasis budaya lokal dibandingkan dengan rata-rata skor minat belajar kelompok siswa yang menggunakan pendekatan kontekstual adalah siswa yang mengikuti pembelajaran matematika dengan pendekatan kontekstual berbasis budaya lokal lebih senang dan bersemangat karena diberikan ketrampilan berupa melukis motif Batik Kawung menggunakan bentuk-bentuk lingkaran, ketrampilan memainkan alat musik rebana, penambahan pengetahuan mengenai legenda Goa Kiskendo, Goa Sumitro, dan Goa Seplawan, serta siswa mengenal bentuk-bentuk gerakan kreasi baru dalam Tari Angguk yang menggunakan konsep lingkaran luar segitiga. Dengan adanya keterlibatan siswa dalam semua aspek yang tersebut di atas, menjadikan siswa lebih bersemangat dan memiliki dorongan untuk belajar matematika.

Pemberian kesempatan untuk melaksanakan pameran dan pemberian penghargaan bagi kelompok terbaik dalam menampilkan hasil karya, dapat menumbuhkan minat siswa untuk belajar bagaimana menggunakan bentuk-bentuk lingkaran untuk melukis motif batik sehingga dapat dikemas menjadi tampilan yang menarik. Selain itu, minat belajar 
siswa mengalami peningkatan dengan adanya persaingan sehat antar kelompok untuk menampilkan pameran yang terbaik dan menampilkan kekompakan pukulan rebana yang selaras.

Apabila dilihat dari aspek apresiasi siswa terhadap matematika, pendekatan kontekstual berbasis budaya lokal lebih efektif dibandingkan dengan pendekatan kontekstual. Sama halnya dengan aspek minat, rata-rata skor apresiasi siswa terhadap matematika pada kelompok siswa yang menggunakan pendekatan kontekstual berbasis budaya lokal lebih tinggi dibandingkan dengan rata-rata skor apresiasi terhadap matematika dari kelompok siswa yang menggunakan pendekatan kontekstual. Penggunaan konteks yang lebih beragam yang dituangkan dalam motif batik, cerita legenda suatu tempat, kreasi gerakan tari, dan permainan tradisional mengantarkan siswa untuk memberikan penilaian yang baik kepada matematika. Penilaian kepada matematika ini meliputi aspek kesadaran bahwa matematika bermanfaat untuk kehidupannya sekarang dan kehidupannya di masa yang akan datang serta kesenangan terhadap matematika karena matematika disajikan dalam bentuk-bentuk karya seni dan budaya yang dekat dengan siswa.

Apabila ditinjau dari aspek prestasi belajar matematika, pendekatan kontekstual berbasis budaya lokal tidak lebih efektif dibandingkan dengan pendekatan kontekstual. Walaupun demikian, berdasarkan rata-rata skor posttest kelompok siswa yang menggunakan pendekatan kontekstual berbasis budaya lokal lebih tinggi dibandingkan rata-rata skor posttest kelompok siswa yang menggunakan pendekatan kontekstual. Pada proses pembelajaran dengan pendekatan kontekstual, siswa diberi kesempatan untuk menemukan sendiri konsep-konsep matematika yang dipelajari. Dengan adanya proses ini, siswa memperoleh pemahaman terhadap asal usul suatu konsep matematika. Siswa mengerti proses penemuan konsep matematika dan tidak hanya semata-mata diberi tahu oleh guru.

Berdasarkan uraian tersebut, dapat disimpulkan bahwa apabila ditinjau dari aspek apresiasi siswa terhadap matematika, pendekatan kontekstual berbasis budaya lokal lebih efektif dibandingkan dengan pendekatan kontekstual. Sedangkan apabila ditinjau dari aspek prestasi belajar dan minat belajar matematika, pendekatan kontekstual berbasis budaya lokal tidak lebih efektif dibandingkan dengan pendekatan kontekstual.

Hal lain yang dapat diketahui berdasarkan hasil penelitian ini adalah, sebanyak 7 dari 45 siswa memperoleh skor minat belajar dengan kategori sangat tinggi dan mendapatkan skor pretasi belajar yang lebih dari 75. Sebanyak 17 dari 45 siswa memperoleh skor minat belajar dengan kategori tinggi dan mendapatkan skor prestasi lebih dari 75 serta sebanyak 10 dari 45 siswa memperoleh skor minat belajar dengan kategori sedang dan mendapatkan skor prestasi lebih dari 75.

Selain itu, apabila dilihat berdasarkan perolehan skor apresiasi siswa terhadap matematika dan prestasi belajar, sebanyak 3 dari 45 siswa memperoleh skor apresiasi terhadap matematika dengan kategori sangat tinggi dan skor prestasi yang lebih dari 75. Sebanyak 27 dari 45 siswa memperoleh skor apresiasi terhadap matematika dengan kategori tinggi dan skor prestasi lebih dari 75. Sebanyak 4 dari 45 siswa memperoleh skor apresiasi terhadap matematika dengan kategori sedang dan prestasi belajar lebih dari 75.

Berdasarkan hasil tersebut dapat terlihat bahwa 34 dari 45 siswa yang memperoleh skor prestasi belajar di atas 75, memperoleh skor minat belajar dengan kategori sangat tinggi, tinggi, dan sedang. Selain itu, dapat diketahui bahwa 35 dari 45 siswa yang memperoleh skor prestasi belajar di atas 75 memperoleh skor apresiasi terhadap matematika dengan kategori sangat tinggi, tinggi, sedang, dan rendah. Secara umum dapat disimpulkan bahwa 
minat belajar dan apresiasi siswa terhadap matematika memiliki kontribusi atau andil terhadap prestasi belajar.

\section{SIMPULAN}

Berdasarkan hasil penelitian dan pembahasan tersebut, maka dapat disimpulkan bahwa pembelajaran matematika dengan pendekatan kontekstual berbasis budaya lokal efektif ditinjau dari prestasi belajar, minat belajar, dan apresiasi siswa terhadap matematika; pembelajaran matematika dengan pendekatan kontekstual efektif ditinjau dari prestasi belajar dan apresiasi siswa terhadap matematika, dan terdapat perbedaan keefektifan antara pendekatan kontekstual berbasis budaya lokal dan pendekatan kontekstual, dengan pendekatan kontekstual berbasis budaya lokal lebih efektif dari pendekatan kontekstual ditinjau dari apresiasi siswa terhadap matematika.

Sebagai tindak lanjut dari hasil penelitian ini dapat dikemukakan beberapa saran bagi peneliti lain yang ingin melakukan penelitian dengan pendekatan kontekstual berbasis budaya lokal untuk merencanakan pembelajaran dengan alokasi waktu yang baik, sehingga pelaksanaan pembelajaran dapat sesuai dengan rencana pelaksaaan pembelajaran yang telah disusun. Selain itu, pendekatan kontekstual berbasis budaya lokal dapat diterapkan pada materi-materi lain selain lingkaran. Oleh karena itu peneliti berikutnya dapat melaksanakan pendekatan kontekstual berbasis budaya lokal pada materi-materi lain yang sesuai dengan materi matematika. Pengintegrasian budaya lokal dalam pembelajaran matematika dapat dilakukan dengan menjalin kerja sama dengan sekolah yaitu dengan memasukkan pelatihan kegiatan budaya dalam kegiata ekstrakurikuler sekolah beriringan dengan pelaksanaan pembelajaran menggunakan pendekatan kontekstual berbasis budaya lokal.

\section{DAFTAR RUJUKAN}

Barret, T. (2007). Teaching toward appreciation in the visual arts. In (L. Bresler, Ed.), International handbook of research of arts education . New York, NY: Springer.

Cai, J., Kaiser, G., Perry, B., \& Wong, N. (2009). Effective mathematics teaching from teachers' perpectives: national and cross-national studies. Rotterdam, NL: Sense.

Center for Occupational Research and Development. (1999). Teaching mathematics contextually. Waco, TX: CORD Communications.

Collette, A.T. \& Chiappetta, E.L. (1994). Science instructional in the middle and secondary schools (3rd ed.). New York, NY: Macmillan.

Crawford, M.L. (2001). Teaching contextually: research, rationale, and techniques for improving student motivation and achievement in mathematics and science. Waco, TX: CCI Publishing. Retrieved from https://dcmathpathways.org/resources/teachingcontextually-research-rationale-and-techniques-improving-student-motivation-and

Deal, T.E., \& Peterson, K.D. (1999). Shaping school culture: the heart of leadership. San Francisco, CA: Jossey-Bass.

Elliot, S.N., Kratochwill, T.R., \& Cook, J.L. (2000). Educational psychology: effective teaching, effective learning ( $3 r d$ ed.). Boston, MA: The McGraw-Hill Companies.

Frenzel, A.C., Goetz, T., Pekrun, R., \& Watt, H.M.G. (2010). Development of Mathematics Interest in Adolescence: Influences of Gender, Family, and School Context. Journal of Research on Adolescence, 20(2), 507-537. doi: 10.1111/j.1532-7795.2010.00645.x

Johnson, E.B. (2002). Contextual teaching and learning: what it is and why it's here to stay. Thousand Oaks, CA: Corwin Press. 
Kamaruddin, N.K.Md, Ahmad, W.M.R.W., Amin, Z.Md, \& Alias, M. (2011). A study of the effectiveness of the contextual approach to teaching and learning statistics at the universiti tun hussein onn malaysia (UTHM). International Journal of Arts \& Sciences, 4(25), 305-313. Retrieved from https://search.proquest.com/openview/aa6189aa1 d4245a1986b28d9443379c5/1?pq-origsite=gscholar\&cbl=626342

Kisker, E.E., Lipka, J., Adams, B.L., Rickard, A., Andrew-Ihrke, D., Yanez, E.E., \& Millard, A. (2012). The potential of a culturally based supplemental mathematics curriculum to improve the mathematics performance of Alaska native and other students. Journal for Research in Mathematics Education. 43(1), 75-113. Retrieved from https://www. nctm.org/Publications/journal-for-research-in-mathematics-education/

Koentjaraningrat. (2009). Pengantar ilmu antropologi (Rev.ed). Jakarta, Indonesia: Rineka Cipta.

Köller, O., Baumert, J \& Schnabel, K. (2001). Does interest matter? The relationship between academic interest and achievement in mathematics. Journal for reasearch in mathematics education, 32(5), 448-470. doi: 10.2307/749801

McMillan, J.H. \& Schumacher, S. (2010). Research in education: Evidence-based inquiry (7th ed.). Boston, MA: Pearson Education.

National Council of Teachers of Mathematics. (2000). Principles and standards for school mathematics. Reston, VA: Author.

Ormrod, J.E. (2008). Educational psychology: developing learners (6th ed). Upper Saddle River, NJ: Pearson/Merrill/Prentice Hall.

Reys, R., Lindquist, M., Lambdin, D.V., \& Smith, N.L. (2014). Helping children learn mathematics (14th ed.). Hoboken, NJ: John Wiley \& Sons.

Schunk, D.H., Meece, J.L., \& Pintrich, P.R. (2020). Motivation in education: Theory, research, and applications (4th ed.). Upper Saddle River, NJ: Pearson.

Sears, S.J. (2002). Contextual teaching and learning: A primer for effective instruction. Bloominton, IN: Phi Delta Kappa International.

Stevens, J.P. (2009). Applied multivariate statistics for the social sciences (5th ed.). New York, NY: Routledge.

Suherman Ar., E., Turmudi, Suryadi, D., Herman, T., Suhendra, Prabawanto, S., ... Rohayati, A. (2003). Common textbook Strategi pembelajaran matematika kontemporer (Rev. Ed.). Bandung, Indonesia: JICA UPI.

Vispoel, W.P., \& Austin, J.R. (1995). Success and failure in junior high school: A critical incident approach to understanding students' attributional beliefs. American Educational Journal, 32(2), 377-412. doi: 10.3102/00028312032002377

Williams, D. (2007). The What, why, and how of contextual teaching in a mathematics classroom. Mathematics Teacher. 100(8), 572-575. Retrieved from https://www.nctm. org/Publications/mathematics-teacher

Woolfolk, A. (2009). Educational psychology: Active learning edition (10th ed.) (H.P. Soetjipto \& S.M. Soetjipto, trans.). Yogyakarta, Indonesia: Pustaka Pelajar.

Zahman, A. (2012). Keefektifan pendekatan kontekstual dan pendekatan pemecahan masalah pada pembelajaran matematika ditinjau dari pencapaian kompetensi dasar, kemampuan penalaran, dan komunikasi matematika.Tesis Universitas Negeri Yogyakarta, Indonesia. 